\title{
PLANKTON COMMUNITY, WATER QUALITY AND GROWTH PERFORMANCE OF NILE TILAPIA AS AFFECTED BY HUMIC ACID IN AQUACULTURE PONDS
}

\author{
Mohamed G. Battah ${ }^{1}$, Aida M. Dawah ${ }^{2}$, Ayman A. Ammar ${ }^{2}$ and Mohamed \\ M. Salama ${ }^{2 *}$ \\ ${ }^{1 .}$ Botany department, Faculty of Science, Banha University, Egypt \\ ${ }^{2}$ Central Laboratory for Aquaculture Research (CLAR), abbassa, Abou-Hammad, \\ Sharkia, Egypt.
}

\begin{abstract}
This study was carried out at Wady El-Ryan, Fayoum Governorate, Egypt to evaluate the influence of humic acid on enrichment of plankton community, water quality, growth performance and pond productivity of Nile tilapia. Eight earthen ponds of a total area of two feddan were used. These fish ponds were divided into four treatments; two replicates per each as the first treatment ponds ( $\mathrm{T} 1$ and $\mathrm{T} 2$ ) were stocked with Nile tilapia fry $14000 \mathrm{fish} /$ Fadden. The second ponds (T3 and T4) were stocked with 28000 fish/Fadden. T2 and T4 treatment ponds received only supplemental feed at a rate of 3\% of body weight (bw), while $\mathrm{T} 1$ and $\mathrm{T} 3$ were treated with humic acid at a rate of $3 \mathrm{Kg} /$ Feddan during the preparation of the ponds, then they received a supplemental feed adding on it $1.5 \mathrm{Kg}$ of humic acid/ ton feed. Comparison between treatments showed that there were no significant differences ( $p>0.05$ ) in water temperature, salinity, total hardness and total alkalinity. Dissolved oxygen, orthophosphate, Chlorophyll "a", concentrations in T1 and T3 ponds were significantly higher $(\mathrm{p}<0.05)$ than those of T2 and T4 ponds. Free ammonia, nitrate and nitrite concentrations in $\mathrm{T} 2$ and $\mathrm{T} 4$ ponds were significantly higher $(\mathrm{p}<0.05)$ than those of T1 and T3 ponds. Secchi disk reading was significantly higher in T4 ponds than that of the other treatment ponds. Phytoplankton and zooplankton abundances were significantly higher in $\mathrm{T} 1$ and $\mathrm{T} 3$ ponds than those of $\mathrm{T} 2$ and $\mathrm{T} 4$. The final weight of Nile tilapia was maximized at $\mathrm{T} 1$ ponds, while the lowest one was in $\mathrm{T} 4$ ponds.
\end{abstract}

Keywords: Humic acid; Nile tilapia; Water Quality; Phytoplankton; Zooplankton.

\section{Introduction}

Humic acid is one of the major components of humic substances, which are dark brown and major constituents of soil organic matter. Humic substances are excellent natural and organic way to provide a concentrated dose of essential critical nutrients, vitamins and trace elements not only to stabilize the plankton blooms in aquaculture ponds but also to improve water quality. The humic acid 
alone is suitable for freshwater algal production and with better water quality variables (Bakhsh, 2001). Besides, humic acid has the capability of reducing the negative effect of high dosage of nitrogen $(\mathrm{N})$ and phosphorus $(\mathrm{P})$ in treatments. Humic acid acts as supplier and storehouse for $\mathrm{N}$ and $\mathrm{P}$ for algae and phytoplankton in aquatic ecosystem. Some studies have also shown that humic acid can increase the productivity of phytoplankton (Vrana and Votruba, 1995) in environment and laboratory experiments. Humic substances are may eventually prove useful for controlling the growth of noxious cyanobacteria in water environments (Sun et al., 2006). Using of fulvic acid with certain dose improves production performance of tilapia and it has significant differences $(p<0.05)$ for both final body length and weight (Wet and Visagie, 2010). The fish exposed to humic acids were significantly longer and heavier than the control group (Meinelt et. $\boldsymbol{a l}, \mathbf{2 0 0 3}$ ) and they added that all the treatment groups exposed to humic acids continued steady growth after stress (2 weeks of daily nettings). Dietary humic acid supplementation during growing period at certain dose rate can be used to improve body weight gain and feed efficiency (Avic et al., 2007). The aim of this study was to investigate the potential use of humic acid in improving productivity (plankton) and provide more insight on water quality variables in a freshwater aquaculture, Suitability of pond water for fish production.

\section{Materials and Methods}

The present study was conducted in eight earthen ponds $8400 \mathrm{~m}^{2}$ surface areas each, $150 \mathrm{~cm}$ water depth. The ponds were prepared by drying for about two weeks before the beginning of the experiment. Ponds were located at Wadi ELRyan, Fayoum Governorate, Egypt. Ponds were filled with water from drainage canal. The ponds were divided into two groups; first group with humic acid as 3 $\mathrm{Kg}$ / Faddan before stocking with fish and second group without humic acid

Humic acid in the experiment was procured from a Turkish company by an Egyptian sole agent (IBN ELWALED CO.) as commercial product HUMAPOL fertilizer which consists of Humic and Fulvic acid, Manganese, Zinc, Iron, Copper, Cobalt, Iodine Selenium, and Koalin, 850, 5.00, 6.00, 60, 5.00, 0.20, $1.00,0.17$, and $2.00 \mathrm{gm} / \mathrm{kg}$ respectively as the company report.

The groups of the experiment divided as:

\begin{tabular}{|c|c|c|c|c|}
\hline \multirow{2}{*}{ Tretments } & \multicolumn{2}{|c|}{ Group one } & \multicolumn{2}{c|}{ Group two } \\
\cline { 2 - 5 } & (T1) & (T2) & (T3) & (T4) \\
\hline $\begin{array}{c}\text { Number of } \\
\text { Fish/faddan }\end{array}$ & 14000 & 14000 & 28000 & 28000 \\
\hline Humapol & present & without & present & without \\
\hline
\end{tabular}


These treatments were assigned to ponds at random in a completely randomized block design and each was replicates two times. Ponds were stocked with Nile tilapia (Oreochronis nilotics) with initial weight was $10 \mathrm{~g} / \mathrm{fish}$. The experimental period was 24 weeks.

Fish samples were taken monthly about $200 \mathrm{fish} /$ pond for calculating the growth performance and the feed quantity per pond, the pellets of feed $27 \%$ protein was used throughout the experiment and was provided twice daily five days/week at a rate of $3 \%$ of body weight for fish in each pond.

\section{Water quality}

Temperature $\left({ }^{\circ} \mathrm{C}\right)$ and dissolved oxygen $(\mathrm{DO} \mathrm{mg} / \mathrm{L})$ were measured by oxygen meter (Aqualytic OX24). Salinity (g/L) and $\mathrm{pH}$ were measured bi-weekly using $\mathrm{pH} /$ conductivity meter (Orion 543). Secchi disk $(\mathrm{SD} \mathrm{cm}$ ) visibilities, ammonia $(\mathrm{mg} / \mathrm{L})$, nitrite $(\mathrm{mg} / \mathrm{L})$, nitrate $(\mathrm{mg} / \mathrm{L})$, total alkalinity as $\mathrm{CaCO}_{3}$ $(\mathrm{mg} / \mathrm{L})$, total hardness $(\mathrm{mg} / \mathrm{L})$, orthophosphate $(\mathrm{mg} / \mathrm{L})$ and Chlorophyll "a" $(\mu \mathrm{g} / \mathrm{L})$ were also measured once a two week using standard methods (APHA, 2000).

\section{Phytoplankton}

Phytoplankton in the sample was concentrated by settling $500 \mathrm{ml}$ sample in a volumetric cylinder for about 24 hours after being preserved in lugols solution (prepared by dissolving $20 \mathrm{gm}$ of potassium iodine (KI) and $10 \mathrm{gm}$ of iodine crystal in $200 \mathrm{ml}$ distilled water solution containing $20 \mathrm{ml}$ glacial acetic acid), at a ratio $0.3 \mathrm{ml}$ lugols solution to $50 \mathrm{ml}$ sediment (APHA, 1985). The surface water was siphoned and the sediment was examined. One ml of sample was transferred into Sedgwick-Rafter cell and counted microscopically. Three replicates of each sample were investigated. Different algal species were identified according to (Prescott, 1962 and 1978). Phytoplankton cells were identified to four divisions, which are: green algae (Chlorophyceae), blue-green algae (Cyanobacteria), diatoms (Bacillariophyceae), and euglena (Euglinophyceae) and different species were identified and counted. All colonial, filamentous and unicellular organisms were counted as one unit (cell). The equation was used to determine phytoplankton diversity according to (Shannon and Weaver, 1949).

Zooplankton: Water sample of $10 \mathrm{~L}$ was collected from each pond by $20 \mu \mathrm{m}$ pore size plankton net. The samples were measured biweekly during the experiment.

Growth performance: Growth performance was determined and feed utilization was calculated as follows:

Weight gain $(\mathbf{g})=\mathbf{W t}_{\mathbf{2}}-\mathbf{W t}_{\mathbf{1}}$; where $\mathbf{W t}_{\mathbf{1}}$ and $\mathbf{W t}_{\mathbf{2}}$ are the initial and final fish weight, respectively. 
Daily Weight Gain (DWG) was calculated as: $\left(\mathbf{W t}_{\mathbf{2}}-\mathbf{W t}_{\mathbf{1}}\right) / \mathbf{t}$

Where:

$\mathrm{Wt}_{1}=$ initial fish weight in grams.

$\mathrm{Wt}_{2}=$ final fish weight in grams.

$\mathrm{t}=$ period in day.

Specific growth rate $(\mathbf{S G R})=\left(\mathbf{L n} \mathbf{w t}_{2}-\mathbf{L n} \mathbf{W t}_{1}\right) \times 100 / \mathrm{t}$.

Where:

$\mathbf{L n}=(\log 10 \mathrm{x})^{3.303}$

$\mathbf{t}=$ is the number of days in the feeding period.

Food conversion ratio (FCR): The food conversion ratio was calculated according to following equation:

$F C R=\longrightarrow$ Total feed consumption $(g)$

Final body weight $(g)$ - initial body weight $(g)$

\section{Statistical analysis}

Statistical analysis was performed using the analysis of variance (ANOVA) and Duncan's multiple range tests to determine differences among treatments. All statistics were carried out by using Statistical Analysis Systems (SAS) program (SAS, 2000).

\section{Results and Discussion}

Bi-weekly monitored water quality parameters are summarized in Table (1). All parameters were within an acceptable range for tilapia culture under Egyptian conditions (Shaker, 2008). There were significant differences in water quality parameter between treatments with and without humic acid fertilizer treatment ponds; and different stocking density. The $\mathrm{pH}$ values were $8.5 ; 9.4 ; 8.6$ and 9.2 for T1; T2; T3 and T4 respectively. This variation could be explained by the photosynthetic uptake of $\mathrm{CO}_{2}$ and bicarbonate that substituted hydroxyl ions. These results indicated that the using of humic acid fertilizer and increased fish density were effected significantly on $\mathrm{pH}$ values (Shaker and Mahmoud, 2007).

Temperature ranged from 28.4 to $28.8^{\circ} \mathrm{C}$ in the treatments during the whole period. Secchi disc reading was significantly higher $(\mathrm{P}<0.05)$ in $\mathrm{T} 2$ and $\mathrm{T} 4$ than in $\mathrm{T} 1$ and $\mathrm{T} 3$ treatments. These results showed low productivity of water in the T2 and T4 treatment than other treatments. Also, the SD was significantly decreased $(\mathrm{P}<0.05)$ in humic acid fertilizer treatments than without humic acid fertilizer treatments. These results are agreed with (Sa'nchez-marin and Beiras, 2011) 
who found that addition of humic acid fertilizer stimulates the growth of phytoplankton and zooplankton causing low water transparency in reading. Dissolved oxygen concentration was significantly $(\mathrm{P}<0.05)$ higher in $\mathrm{T} 1$ and $\mathrm{T} 3$ treatments than in the other treatments Table (1). These results may be due to the increase of photosynthetic led to increasing of DO production by phytoplankton (Shaker, 2008). The concentration of nitrate and phosphate showed significance higher $(\mathrm{P}<0.05)$ values in humic acid treatments through the experimental period.

The $\mathrm{pH}$, temperature and dissolved oxygen were the most influencing parameters in fish ponds, where their values in all ponds, although fluctuated from time to time, they stayed within the acceptable and favorable levels required for growth, survival and well being of the tested fish species (Shaker et al., 2013). The decrease of DO concentrations in treatment without humic acid fertilizer may have resulted from the lower grazing pressure by fish, which resulted in larger planktonic communities, subsequently contributing to higher accumulation rates of organic material on the bottom, leading to bacterial decomposition and increased sediment oxygen consumption (Smith and Piedrahita, 1988). Elevated total ammonia concentrations may indicate to higher sediment organic matter accumulation and decomposition rates in these treatments. However, DO levels were always within the optimum range for different fish species in polyculture production in the earthen ponds (Shaker et al., 2009). DO increases feed consumption, feed efficiency, metabolism, and growth of fish (Azim et al., 2005 and Shaker, 2008). Numerous studies have shown increases in oxygen consumption after feeding due to the metabolic cost of digesting and assimilating the nutrients from the feed. The concentration of DO in water is dramatically affected by stocking density, water temperature, water flow and pond management (Shaker and Abdel Aal, 2006; Shaker and Mahmoud, 2007 and Shaker et al., 2009).

Water quality measurements made during the trial indicated that there were statistically significant differences among treatments as a result of the presence of the humic acid fertilizer. There was a trend of higher Secchi disc values for of the presence of humic acid, including phytoplankton, in the water column and lower chlorophyll-a concentrations in water samples from ponds with humic acid, indications that there may be a trade-off between phytoplankton and humic acid activity and phytoplankton production.

The data in Table (1) show the average values of nitrogen compounds in water under different treatments. The average values of $\mathrm{NH}_{3}$ were $0.22 ; 0.59$; 0.16 ; and $0.44 \mathrm{mg} / 1$ for $\mathrm{T} 1$; $\mathrm{T} 2$; $\mathrm{T} 3$ and $\mathrm{T} 4$ respectively. The average values of $\mathrm{NO}_{2}$ were $0.078 ; 0.148 ; 0.06$ and $0.1 \mathrm{mg} / \mathrm{l}$ for the same treatments respectively. 
Mohamed G. Battah et al.

\begin{tabular}{|c|c|c|c|c|}
\hline 总星高 & $\begin{array}{l}\tilde{D}_{0} \\
\dot{\infty}_{\infty}\end{array}$ & 染 & in & $\frac{7}{7}+7$ \\
\hline 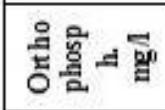 & $\overrightarrow{\tilde{m}}+1$ ह & $\overrightarrow{\vec{s}}$ + & & $\frac{0}{0}+1$ \\
\hline 费的可 & $\ddot{z}+1+\stackrel{0}{0}$ & $\stackrel{n}{2}+\frac{0}{0}$ & & 곤 \\
\hline 路鄫的哥 & in & 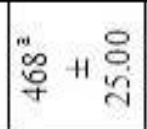 & & 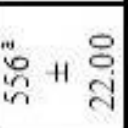 \\
\hline 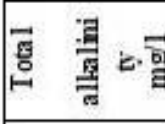 & 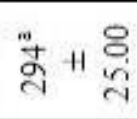 & 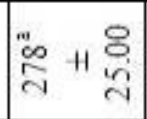 & & \\
\hline 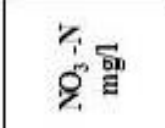 & 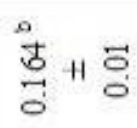 & : & & \\
\hline 音 & 咅+ & 总 + & 응 & : \\
\hline 离 & สี + & 常 & & \\
\hline 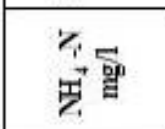 & $\stackrel{\infty}{\stackrel{\infty}{0}}+1=$ & ${ }_{-1}^{\prime \prime}+$ H & & $+1 \frac{7}{0}$ \\
\hline 음햅 & : & $\frac{y}{y}+1+\dot{0}$ & $\left.\tilde{\sigma}_{0}^{\circ}+\right]_{0}^{+}$ & ${ }_{m}^{+}+1 ?$ \\
\hline ڤั & $\stackrel{\circ}{\circ}+1$ & 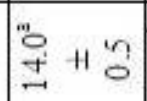 & 总 & 0 \\
\hline 国 & $\stackrel{0}{n}+12$ & $\begin{array}{ll}\prime \prime \\
\alpha\end{array}$ & 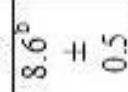 & ${ }_{\alpha}^{\prime \prime}+\vec{z}$ \\
\hline 憲: & 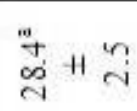 & 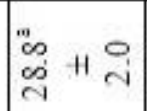 & 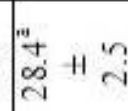 & 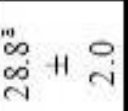 \\
\hline & & $\approx$ & $\Leftrightarrow$ & $\overrightarrow{\vec{H}}$ \\
\hline
\end{tabular}


The increase of $\mathrm{NH}_{3}$ in the treatments without humic acid could be explained by the decomposition of organic matter and via the direct excretion of ammonia by the large biomass of fish. These finding indicated that the humic acid improved water quality. The $\mathrm{NO}_{2}$ and $\mathrm{NO}_{3}$ concentrations in water followed the same trend of ammonia-nitrogen. These results may be due to the consumption of nitrate (which is an essential nutrient) by phytoplankton communities. Also, the increase of nitrate in T2 and T4 may be related to the increase of phytoplankton standing corps. There a positive correlation between nitrate content and total phytoplankton which may be attributed to high consumption rate of $\mathrm{NO}_{3}$ by the algae. These results are in harmony with those obtained by (Shaker $\boldsymbol{e t}$ al., 2009). Water quality is improved through the higher rate of nitrification and ammonia uptake by phytoplankton algae (Thompson et al., 2002 and Shaker et al., 2013). The uneaten feed and dead periphyton cells remain attached with the surface sediment, providing a rich source of organic nutrients for heterotrophs associated with periphyton layer. Processing of this organic matter yields inorganic nutrients that can be utilized by living algae again. However, there is very little opportunity for humic acid treatments to grow in well managed fish culture.

Phosphorus is an element that, in its different forms, stimulates the growth of aquatic macrophytes and algae in water bodies. The average values of dissolved phosphorus in the same treatments were $0.31 ; 0.21 ; 0.32$ and $0.15 \mathrm{mg} / \mathrm{l}$, respectively Table (1). These results clear that the concentration of available phosphorus were significantly decrease $(\mathrm{P}<0.05)$ in $\mathrm{T} 2$ and $\mathrm{T} 4$ treatments.These results may be due to the added of humic acid led to release of phosphorus from the surface layer of soil to water (Singh and Amberger, 1991). The chlorophyll a concentrations in water followed the same trend of phosphorus.

Humic acid assemblages lead to increased retention of nutrients through firstly; it can remove nutrients from the water column and cause a net flux of nutrients toward the sediments (Singh and Amberger, 1991). Second, it can slow water exchange across the sediment/water column boundary thus decreasing advective transport of $P$ away from sediments (Sarir $\boldsymbol{e t}$ al., 2006). Third, they can intercept nutrients diffusing from the benthic sediments or senescent macrophytes. It can cause biochemical conditions that favor $\mathrm{P}$ deposition.

The presented data in Table (1) show the average values of salinity, total alkalinity and total hardness were not significance $(\mathrm{P}<0.05)$ changed in all treatments during the experimental period. These results indicated that the added of humic acid did not affect on salinity, total hardness and total alkalinity.

\section{Plankton algae development}

It has been found that humic acids in the water can affect the development of plankton algae. By the addition of humic acids fertilizer in the water, the development of Chlorophyta and Bacillariophyta was stimulated, while 
the numbers of Cyanophyta in T1 and T3 were lower mainly the development was inhibited than those registered in the other variation T2 and T4. Abundance of phytoplankton was positively affected by HA treatments $(r=0.578 ; \mathrm{P}<0.01)$, and it was significantly higher at T1 and T3 than that of T2 and T4 Table (3).

The maximum number of phytoplanktons was recorded in October T1 and at T3 (181 and 129 org. $/ \mathrm{ml}$ ), respectively while the minimum value was recorded in May and June at T4 (38 and $45 \mathrm{org}$. / $\mathrm{ml}$ respectively). Table (2) shows the different species of each phytoplankton division. The recorded species for each division were 21, 20, 17 and 4 for Bacillariophyceae, Chlorophyceae, Cyanobacteria and Euglenophyceae respectively. Phytoplankton of T2 and T4 was characterized by a predominance of blue-green algae in terms of their numbers. Merismopedia elegans and Phormidium sp dominated. Microcystis aeruginosa and Chrocococcus minutus were subdominant.

Other species such as Lyngbya birgei, Gleocapsa sp., and Oscillatoria hamelii were also present in the ponds. Chlorophyceae such as Oocystis sp., Scenedesmus $s p$ and Tetraedron $s p$ were found to be the most abundant species. In addition, Ankistrodesmus, Chlorella, Closterium sp. and Cosmorim sp. were recorded. The maximum Scenedesmus number was recorded in August in T1 (19 org. $/ \mathrm{ml})$, while the minimum number was obtained in May in T4 (3 org. $/ \mathrm{ml})$. The highest number of Dictyoshaerium sp. was recorded in August in T3 (8 org. $/ \mathrm{ml})$.

The most abundant species of Bacillariophyceae were Navicula sp., Nitzschia sp., and Synedra sp. Other species of Bacillariophyceae were Cyclotella sp., Cymbella sp., Diatoma sp., Gemphonema sp., and Pinnularia sp., Navicula sp. and Nitzschia sp. were the most abundant genera at all treatments during the study period. Navicula sp. exhibited the highest number in September and October at T1, (10 and $12 \mathrm{org} . / \mathrm{ml}$, respectively). The highest number of Nitzschia sp. was recorded in October at T1 $(10 \mathrm{org} . / \mathrm{ml})$ and at T3 $(9 \mathrm{org} . / \mathrm{ml})$. Moreover, Synedra sp. was abundant at T1 and T2, and the highest number was obtained in October in T1 (16 org. $/ \mathrm{ml})$. Euglenophyceae was represented only by the genera Euglena and Phacus. They were not recorded in all treatments during the experimental period. Generally, Phacus was less abundant than Euglena. The high occurrence of Euglena sp. was recorded during May in T4 and Auguest in T1 (4 and $4 \mathrm{org}$. / $\mathrm{ml}$, respectively). In case of Phacus, the highest number was obtained in August in T4 and T1 ( 2 and 3 org. /ml, respectively). During May, diatoms appeared as the most abundant group in $\mathrm{T} 1$ with variable contributions at each treatment. On the other hand, the green alga species followed the dominant diatoms in abundance during May. In June, the contributions of the algal groups were approximately similar to that found in May. During the period of June Cyanophyceae was constituted a large part of phytoplankton and Euglenophyceae was the least, Fig. (1). 
Plankton Community, Water quality and Growth Performance of Nile Tilapia as Affected by

Table 2. Monthly variation in phytoplankton species in earthen ponds stocked with Nile tilapia and subjected to humic acid fertilizer

\begin{tabular}{|c|c|c|c|c|c|c|c|c|c|c|c|c|c|c|c|c|c|c|c|c|c|c|c|c|}
\hline \multirow{4}{*}{\begin{tabular}{l}
\multicolumn{1}{c}{$\begin{array}{c}\text { Phytoplankton } \\
\text { species }\end{array}$} \\
Bacillariophyceae \\
Amphora ovalis
\end{tabular}} & \multirow{3}{*}{ May } & \multicolumn{5}{|c|}{ T1 } & & & & T2 & & & & & & T3 & & & & & & T4 & & \\
\hline & & Ju & July & & & Oct. & May & June & July & & Sept & Oct. & May & June & July & Aug & Sept & Oct. & May & June & July & Aug. & Sept & Oct. \\
\hline & & & & & & & & & & & & & & & & & & & & & & & & \\
\hline & - & - & 1 & 1 & - & - & - & - & - & 1 & - & - & 1 & - & - & 1 & - & - & - & - & - & - & 2 & 1 \\
\hline Cyclotella meneghiniana & 1 & 1 & 4 & 2 & 3 & 4 & 1 & - & 2 & - & 2 & 3 & - & - & - & - & 3 & 3 & - & - & - & - & 2 & 1 \\
\hline Cymbella affinis & 2 & 1 & 1 & 2 & 4 & 5 & - & - & & - & 1 & 1 & - & - & 1 & - & 2 & 3 & - & - & - & - & 1 & 2 \\
\hline C. silesiaca & - & 1 & - & 1 & 4 & 5 & 2 & - & 2 & 2 & 2 & 2 & 1 & - & - & 1 & - & 4 & - & - & - & 1 & 2 & - \\
\hline Cymbella sp. & 1 & - & - & - & 4 & 4 & - & - & - & - & 1 & 1 & - & - & - & 2 & 1 & 4 & 1 & 2 & - & 1 & - & 2 \\
\hline Diatoma mesodon & - & 1 & 1 & 2 & 4 & 6 & - & & 2 & - & 3 & 2 & - & - & 1 & - & 4 & 3 & - & 1 & 1 & 1 & 1 & 2 \\
\hline D. vulgaris & - & 1 & 3 & 3 & 4 & 6 & - & 2 & - & - & 2 & 1 & 1 & - & - & - & 4 & 6 & 1 & - & - & - & 2 & - \\
\hline Fragilaria capucina & 1 & 2 & - & 2 & 2 & 2 & 1 & - & - & - & - & - & 2 & - & - & 2 & 2 & 2 & - & - & - & - & 2 & - \\
\hline Gomphonema gracile & 1 & 1 & 2 & 3 & 3 & 5 & - & - & 2 & - & 2 & 2 & - & 3 & - & 1 & 3 & 5 & 1 & - & 1 & 1 & - & 2 \\
\hline G. olivaceum & - & - & - & 2 & 2 & - & - & - & - & 2 & 3 & 3 & 1 & 1 & 2 & 1 & 2 & - & 1 & 2 & - & - & 2 & 1 \\
\hline Gomphonema sp. & 1 & & 4 & 3 & 7 & 8 & 1 & - & - & - & 4 & 3 & - & - & 2 & 2 & 4 & 5 & 1 & 1 & - & - & - & - \\
\hline Navicula radiosa & - & 2 & 3 & 2 & 6 & 7 & - & - & 2 & - & 1 & 2 & 1 & 2 & 1 & 2 & 5 & 7 & - & - & 2 & 1 & - & - \\
\hline Navicula sp. & 2 & 1 & 1 & 2 & 4 & 5 & - & - & - & - & 2 & 1 & 2 & 1 & 1 & 3 & 4 & 5 & - & 3 & 2 & - & 1 & 2 \\
\hline Nitzschia alpina & - & - & - & - & 3 & 3 & - & 2 & - & - & 1 & 1 & - & 2 & 2 & 1 & 2 & 3 & 1 & 1 & - & - & 1 & 1 \\
\hline N. closterium & 1 & - & 1 & 1 & 3 & 4 & - & - & - & 2 & - & 2 & 2 & 2 & 1 & 2 & 2 & 3 & - & - & - & - & - & 1 \\
\hline N. palea & - & - & - & - & 2 & 1 & 1 & 2 & - & - & - & - & - & - & - & - & - & 1 & - & - & - & - & - & - \\
\hline N. radicula & - & 2 & - & - & - & 2 & - & - & - & - & - & - & - & - & - & - & - & 2 & - & - & - & - & - & 1 \\
\hline Pinnularia $s p$. & 1 & 2 & - & - & 1 & 1 & - & - & 2 & - & - & 1 & - & - & - & - & - & 1 & - & - & - & - & - & - \\
\hline Synedra acus & 2 & 2 & 3 & 2 & 4 & 5 & 1 & - & - & - & 2 & 3 & - & - & - & - & 2 & 5 & - & - & - & - & 1 & 2 \\
\hline Synedra ulna & - & - & - & - & 2 & 3 & - & - & 2 & - & 1 & 3 & - & - & - & - & 1 & 3 & - & - & - & - & 1 & 1 \\
\hline Synedra sp. & - & 1 & - & - & 6 & 8 & 1 & 1 & - & - & 3 & 2 & 1 & 1 & 3 & - & 4 & 4 & - & - & - & 2 & 2 & 2 \\
\hline Chlorophyceae & & & & & & & & & & & & & & & & & & & & & & & & \\
\hline Ankistrodesmus braunii & 1 & 2 & 3 & 5 & - & - & - & 2 & 1 & 1 & - & - & - & - & 2 & - & 3 & - & - & - & - & 2 & - & - \\
\hline A. convolutus & - & - & - & - & - & - & - & - & - & - & - & - & - & - & - & 1 & - & - & - & - & - & - & - & - \\
\hline A. falcatus & - & - & 1 & 1 & - & - & - & - & - & - & - & - & 1 & 2 & - & - & - & 2 & - & - & - & - & - & - \\
\hline A. setigera & - & - & 2 & & - & 2 & - & - & - & - & - & - & - & - & - & 3 & - & - & - & - & - & - & - & - \\
\hline Ankistrodesmus sp. & - & 2 & 5 & 8 & 1 & - & - & 2 & 1 & 2 & - & 1 & 2 & 3 & 3 & 5 & 7 & 9 & 1 & 1 & 3 & - & 6 & - \\
\hline Chlorella vulgaris & 3 & 4 & 11 & 11 & 13 & 17 & 5 & 2 & 2 & 5 & 8 & 13 & 3 & 1 & 8 & 11 & 14 & 9 & 3 & 8 & 6 & 4 & 6 & 8 \\
\hline Closterium sp. & 2 & - & 2 & 4 & 2 & - & - & 2 & - & 2 & - & - & 3 & 3 & - & 3 & - & 5 & - & - & 2 & 2 & 2 & 3 \\
\hline Cosmorium $s p$. & - & - & - & 2 & - & - & - & 1 & - & - & - & - & 1 & - & - & - & - & - & - & - & - & - & 2 & - \\
\hline Dictyoshaerium $s p$ & - & - & - & 3 & - & - & - & - & - & - & 3 & - & - & 2 & 5 & 8 & 5 & - & - & - & - & 2 & - & - \\
\hline Gomphoshaeria sp & 1 & - & - & 4 & - & - & - & - & 1 & - & - & - & 1 & - & 3 & 5 & 3 & 3 & - & - & - & 1 & - & 1 \\
\hline Oocystis limneticus & - & 1 & 5 & 7 & 10 & 8 & - & 2 & 4 & 3 & - & 1 & 1 & 2 & - & 2 & 3 & 2 & 2 & 2 & - & 2 & - & - \\
\hline Oocystis solitaris & 1 & 1 & 6 & 9 & 6 & 4 & - & - & - & & - & - & - & - & - & - & 2 & - & - & - & - & - & - & - \\
\hline Oocystis sp. & 2 & 3 & 11 & 8 & 6 & 6 & 2 & - & 1 & 5 & 5 & - & 1 & 1 & 3 & 2 & 1 & 3 & - & - & 5 & 5 & - & 4 \\
\hline Scenedesmus acuminatus & 3 & 5 & 9 & 17 & 6 & 3 & 3 & 3 & 3 & 8 & 11 & 9 & 2 & 2 & 6 & 5 & 7 & - & 3 & 5 & 4 & 4 & - & - \\
\hline S. quadricauda & - & - & 1 & - & 1 & - & - & - & - & - & - & - & - & - & - & 1 & - & - & - & - & - & - & - & - \\
\hline Scenedesmus sp. & - & 2 & - & 2 & - & - & - & - & - & 2 & - & - & - & - & - & 3 & - & 2 & - & - & - & - & - & - \\
\hline Selenastrum sp. & 1 & 2 & - & 3 & 3 & - & - & - & 1 & 3 & - & - & 1 & - & - & 2 & - & 2 & 2 & - & - & 1 & - & 2 \\
\hline Tetraedron caudatum & - & - & - & 1 & 1 & - & - & - & - & 1 & - & - & - & - & - & 1 & - & - & - & - & - & - & - & - \\
\hline Tetraedron minimum & - & - & 2 & 2 & 3 & - & - & 2 & 2 & 1 & - & 1 & 2 & 2 & 2 & 1 & - & 1 & - & - & - & 2 & 1 & 4 \\
\hline Tetraedron $s p$ & 4 & 5 & 4 & 8 & 11 & 2 & - & 5 & 3 & 5 & 3 & 1 & 1 & 1 & 3 & 2 & 1 & 1 & 2 & 2 & 1 & 2 & 1 & 1 \\
\hline Cyanobacteria & & & & & & & & & & & & & & & & & & & & & & & & \\
\hline Anacystis $s p$ & - & 4 & - & 2 & - & - & - & - & 3 & - & 1 & - & 2 & - & - & 2 & - & 3 & - & - & 1 & 3 & 2 & - \\
\hline Chroococcus minutus & 2 & 6 & 13 & 7 & 9 & 7 & 2 & 1 & - & 2 & - & 1 & 3 & - & 1 & 4 & 5 & 2 & 2 & 8 & 6 & 8 & 7 & 3 \\
\hline Chrooc & 1 & 2 & 3 & - & - & - & 2 & - & - & 2 & - & - & 1 & 4 & 3 & - & 3 & 1 & 3 & 2 & - & - & - & - \\
\hline Gleocapsa sp. & - & - & - & 4 & - & - & 1 & - & - & - & - & - & 1 & - & 2 & - & - & 2 & 2 & - & - & - & 2 & 1 \\
\hline Lyngbya birgel & 1 & 1 & - & 1 & - & - & - & 2 & - & - & - & - & - & - & - & 3 & - & - & - & 1 & - & - & 1 & 1 \\
\hline Merismopedia glauca & - & - & 2 & - & 4 & - & 2 & 7 & 3 & - & - & - & - & 5 & - & 2 & - & - & - & - & 3 & 2 & - & - \\
\hline M. punctata & 3 & - & - & - & 2 & - & - & - & - & 2 & - & - & - & 2 & - & 2 & - & - & - & - & - & - & - & - \\
\hline M. tenuissima & - & - & 2 & - & - & - & - & - & - & 3 & - & - & - & 1 & - & 3 & - & 1 & - & 2 & - & - & 1 & 2 \\
\hline Merismopedia sp. & 2 & - & 6 & 8 & - & - & 2 & - & 2 & - & - & - & 2 & 2 & - & - & 3 & - & - & - & - & 3 & - & - \\
\hline Microcystis aeruginosa & - & - & 2 & - & 3 & - & - & 3 & 3 & 3 & 2 & - & 1 & 1 & 2 & 1 & 1 & 1 & 2 & 2 & 2 & 1 & 2 & 1 \\
\hline Microcystis flos-aquae & - & 2 & - & - & 3 & - & - & - & - & 2 & - & - & - & - & - & 1 & - & - & & - & - & 1 & - & - \\
\hline Microcystis sp. & 2 & - & - & - & - & 1 & 1 & 1 & 1 & 3 & - & - & - & - & 2 & - & 1 & 1 & 2 & - & - & 1 & - & - \\
\hline Oscillatoria hamelii & - & - & - & - & - & - & - & - & - & - & - & - & - & - & - & 1 & - & - & - & - & - & - & - & - \\
\hline O.rubescens & - & - & - & - & - & - & - & 1 & - & - & - & - & - & - & - & 1 & - & - & - & - & - & - & - & - \\
\hline O.tenuis & 2 & 2 & - & 3 & - & - & 2 & 1 & - & 2 & - & - & 1 & - & 2 & - & 3 & 2 & - & - & - & 1 & - & - \\
\hline phormidium $s p$. & 4 & 7 & 11 & 14 & 8 & 3 & 3 & - & 4 & 6 & 3 & - & 2 & 5 & 9 & 7 & 5 & 5 & 2 & - & 3 & - & 2 & 1 \\
\hline Euglenophyceae & & & & & & & & & & & & & & & & & & & & & & & & \\
\hline Euglena acus & - & - & 1 & 2 & 1 & - & 1 & - & - & 1 & 2 & 3 & - & 1 & 2 & 1 & 2 & - & 1 & - & - & 1 & 2 & - \\
\hline Eugle & - & - & - & 2 & 2 & 2 & 1 & 1 & 1 & - & - & - & 1 & - & - & 2 & - & 1 & 3 & 2 & - & - & 1 & 3 \\
\hline Phacus longcal & - & - & - & - & - & - & - & - & - & 1 & - & - & - & - & - & - & - & - & - & - & - & - & - & - \\
\hline Phacus sp. & - & 1 & - & 3 & 2 & - & 1 & - & 1 & 1 & 1 & 2 & 1 & - & - & - & 1 & 2 & 1 & _- & - & - & - & 1 \\
\hline
\end{tabular}

Egyptian J. of Phycol. Vol. 14, 2013 
Mohamed G. Battah et al.

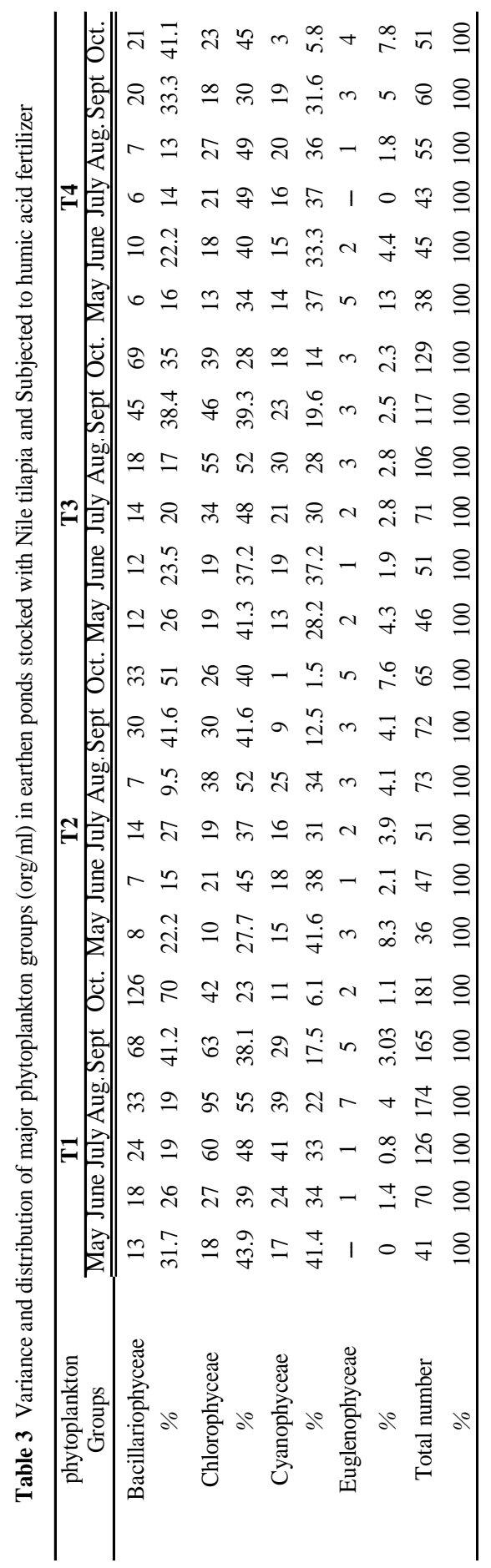




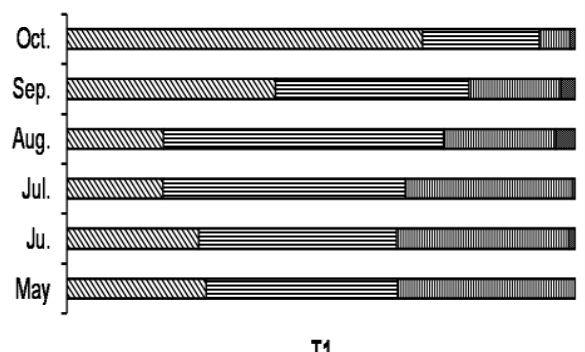

T1
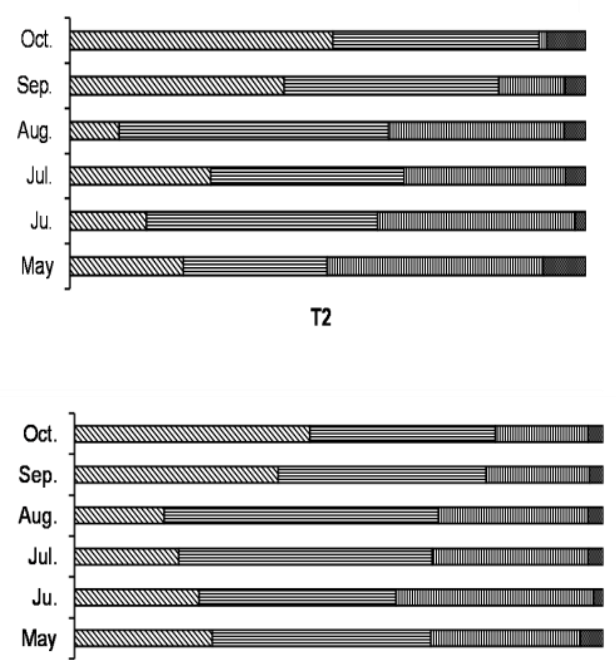

T3

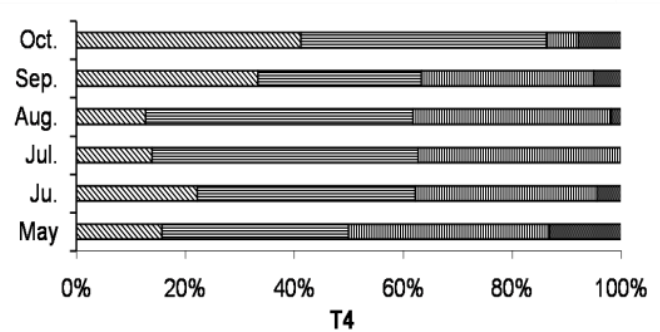

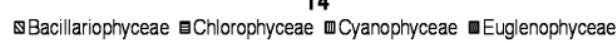

Fig. 1. Monthly variations in percentage composition of different phytoplankton groups in the different treatments (T1, T2, T3 and T4) during the experimental period. 
In August, green algae became again the predominant (52-57\%), while diatoms mostly ranked the second abundant group with two exceptions at T1 and T3. During the first half of September, green algae were still dominant in the whole area, replaced alternatively in late September and October by diatoms and blue-green algae, Fig. (1).

The T1 and T3 ponds exhibited high number of phytoplankton organisms in comparison to that of $\mathrm{T} 2$ and $\mathrm{T} 4$. This result might be was proportional to the daily rate of humic acid addition and that was similar to (Carlsson et al, 1995) who found that addition of humic acid stimulates bacterial, phytoplankton and ciliated growth in coastal waters and that humic bound nitrogen is to some extent available for phytoplankton. Humic substances may have something to do in the improvement of the photosynthetic activity and efficiency observed, through a direct and/ or indirect stimulatory effect on the algal community, (Conzonno and Cirelli, 1996). The number of phytoplankton depended mainly on the number of Cyanophytceae and Chlorophyceae, which were the most abundant groups ( $\mathrm{r}=$ 0.956 and 0.931 , respectively; $\mathrm{P}<0.05$ ), while Bacillarophyceae and Euglenophyceae were the less abundant ones in all treatments $(r=0.605$ and 0.189 , respectively; $\mathrm{P}<0.05$ ). The sensitivity of Cyanobacteria to humic acid may also explain patterns in the field. Thus, ponds which were treated with humic acid do not support the Cyanobacterial blooms; the opposite of poor humic ponds (T2 and T4). Thus, Cyanobacteria appear to be unable to use their accessory pigments (particularly phycocyanin) to exploit the reddish light prevailing in humic-rich lakes (Keskitalo and Eloranta, 1998). Addition of humic acids has a large effect on phytoplankton composition, since it stimulates the growth of chlorophyceae and Bacillariophyceae while it has negative effect on Cyanophyta, (Klochenko et $\boldsymbol{a l}, \mathbf{2 0 1 1}$ ). High numbers of Bacillarophyceae (diatoms) were presented in treated ponds which were characterized by daily addition of HA have than T2 \& T4 since humic acid has a stimulatory action on growth of diatoms (Prakash et.al, 1973). Spore formation of Bacillariophyceae can be induced by high temperature $\left(24^{\circ} \mathrm{C}\right)$ whereas low temperatures defer it (Adolf et al., 2009); this explains the lowest number of Bacillariophyceae during high temperature period. Euglenophyceae increase coincides with high eutrophication levels, (Taniguchi et al., 2005); while humic substances prevent and make remediation of eutrophication (Steinberg $\boldsymbol{e t}$ al, 2008).

\section{Zooplankton Abundance}

The common zooplankton groups were Cladocera, Copepods and Rotifers in all treatments. Rotifer was dominant zooplankton group, while Copepods, Cladocera and Ostracoda exhibited sub-abundance in all treatments Table (4). Zooplankton abundance was positively affected by HA treatments $(\mathrm{r}=0.420$; $\mathrm{P}<0.01)$ and it was greater in $\mathrm{T} 1$ and $\mathrm{T} 3$ than that of $\mathrm{T} 2$ and $\mathrm{T} 4(\mathrm{P}<0.05)$. The maximum number of zooplankton was obtained in October at T1 $(87 \mathrm{org}$. /L) 
followed that in T3 $(86 \mathrm{org} / \mathrm{L})$. The minimum number of zooplankton of $23 \mathrm{org}$. $/ \mathrm{L}$ was recorded in T2 and 19 org. /L in T4 ponds in May Table (4). Dominant Cladocera included Moina, Bosmania, Diaphanosoma and Daphnia. Cyclops was the most common copepod and common Rotifers included Brachionus and Keratella. Cypris was the most common of Ostracoda.

A positive correlation between the content of the humic substances and the total number of zooplankton was found in $\mathrm{T} 1$ and $\mathrm{T} 3$. (Gutseit $\boldsymbol{e t}$ al., 2007) showed that there are differences in food quality between humic and clear waters that affect zooplankton growth and reproduction. The large influence of humic substances can have bearings on food quality for zooplankton, since it can affect, for instance, the relative contribution of algal (high food quality), non-algal and detrital (low food quality) carbon to the total organic carbon pool, as well as microplankton community structure and composition (Hessen et al., 1989). In treated humic water, rotifers appear to predominate in the zooplankton (Kankaala, 1988), although in some cases cladocerans are a substantial component (Hessen et al., 1989). Phosphorus contents in treatment T1 favored species with a fast reproduction rate and short life span of organisms, such as Rotifera. Rotifers and small copepods are known to be more tolerant of adverse environmental conditions than the cladocerans (Hannson et al., 2007). As previously, humic acid led to improving water quality and extends algae with essential nutrients which are necessary for their growth; thus, zooplankton growth.

Zooplankton can consume a substantial portion of phytoplankton, but zooplankton- phytoplankton relationships within Wadi-EL Rayan area were variable seasonally and among sites (Nehad and Howayda, 2010). In subtropical and tropical lakes grazing by zooplankton is of little importance for controlling the phytoplankton community structure and biomass (Crisman and Beaver, 1990). The phytoplankton densities in the present fish ponds were correlated with the densities of zooplankton in the same ponds. This may be due to two main factors: the regeneration of the nutrients by zooplankton leads to increase the abundance of phytoplankton (Janik, 1989), and the predation of the fishes on large zooplankton leads to the development of phytoplankton (Elhigzi et al, 1995). Planktivorous fish are known to be size-selective predators that prey selectively on largest zooplankton (Zaret, 1980). The present data are concurrent with this observation since the small rotifers and the nauplius larvae of copepods were the most dominant in fish ponds. Micro zooplankton (rotifers, nauplius larvae, ciliates, and heterotrophicflagellates) develops better when predatory pressure by zooplankton crustaceansis reduced (Richardson et al, 1990). 
Mohamed G. Battah et al.

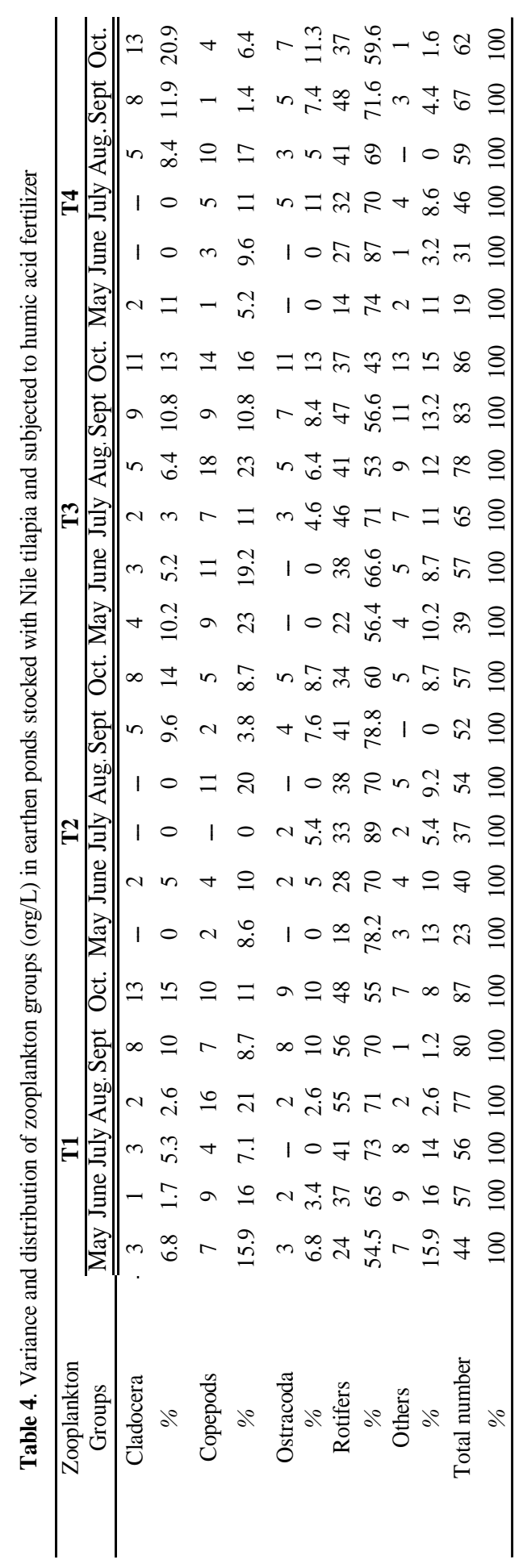


Brett and Goldman (1996) found that removing large and more conspicuous zooplankton, lefts back small crustaceans and small rotifers. Diana et.al (1991) tested the trophic cascade hypothesis in aquaculture ponds containing tilapia at different densities. They detected that fish predations affect not only the prey, but also lower trophic levels. They found that zooplankton densities, particularly small zooplankton were reduced in ponds without fish.

\section{Growth Performance}

As presented in Table (5), survival rate, final weight, net gain, daily gain and total and net production of fish production were significantly $(\mathrm{P}<0.05)$ increase in highest stocking density in both with and without humic acid than lowest stocking density with and without humic acid treatments. The survival rate of tilapia was $99.5 ; 99.5 ; 100$ and $100 \%$ for treatmrnt1, treatment 2 ; treatment 3 and treatment 4 respectively. The higher survival in humic acid treatments with highest stocking density might result from the availability of nutrient as additional food and shelter for protection from predators.

Table (5): Growth performance of two stocking density of $O$. niloticus with Humapol (humic acid) fertilizer treatments and without in earthen ponds.

\begin{tabular}{|c|c|c|c|c|}
\hline Treat. & Treatment 1 & Treatment 2 & Treatment 3 & Treatment 4 \\
\hline Initial weight g & $10.0 \pm 1.0^{\mathrm{a}}$ & $10.0 \pm 1.0^{\mathrm{a}}$ & $10.0 \pm 1.0^{\mathrm{a}}$ & $10.0 \pm 1.0^{\mathrm{a}}$ \\
\hline Final weight g & $296.4 \pm 24.5^{\mathrm{a}}$ & $241.1 \pm 20.2^{\mathrm{c}}$ & $263.7 \pm 22.5^{\mathrm{b}}$ & $217.6 \pm 18.5^{\mathrm{d}}$ \\
\hline Weight gain g & $285.5 \pm 23.5^{\mathrm{a}}$ & $230.6 \pm 20^{\mathrm{c}}$ & $253.2 \pm 21.2^{\mathrm{b}}$ & $207 \pm 18^{\mathrm{d}}$ \\
\hline Daily gain g & $1.59 \pm 0.15^{\mathrm{a}}$ & $1.28 \pm 0.12^{\mathrm{c}}$ & $1.41 \pm 0.12^{\mathrm{b}}$ & $1.15 \pm 0.1^{\mathrm{c}}$ \\
\hline $\begin{array}{c}\text { Survival rate \% } \\
\text { Total prod. Pond kg }\end{array}$ & $99.5 \pm 0.5^{\mathrm{a}}$ & $99.5 \pm 0.5^{\mathrm{a}}$ & $100 \pm 0.0^{\mathrm{a}}$ & $100 \pm 0.0^{\mathrm{a}}$ \\
\hline $\begin{array}{c}\text { SGR } \\
\text { Feed consummation } \\
\text { Kg }\end{array}$ & $1140.2 \pm 150^{\mathrm{c}}$ & $5896.1 \pm 140^{\mathrm{d}}$ & $13081.4 \pm 350^{\mathrm{a}}$ & $11644.8 \pm 280^{\mathrm{b}}$ \\
\hline $\begin{array}{c}\text { Feed conversation } \\
\text { ratio }\end{array}$ & $1.1 \pm 0.1^{\mathrm{c}}$ & $1.72 \pm 0.1^{\mathrm{b}}$ & $1.84 \pm 0.1^{\mathrm{b}}$ & $2.13 \pm 0.1^{\mathrm{a}}$ \\
\hline
\end{tabular}

Survival, growth, weight gain, daily gain and total production of tilapia were significantly $(\mathrm{P}<0.05)$ higher in the ponds provided with additional humic acid than those in the same treatments without humic acid Table (5), which may 
be attributed to the high productivity and readily available food in the form of humic acid treatments. A similar production enhancement was reported by (Ramesh et al., 1999) and (Azim et al., 2005) through the provision of additional humic acid. Algae growing on humic acid treatments and the associated bacterial and zooplanktonic biomass can be directly exploited by many herbivorous fish species (Huchette et al., 2000), resulting in a higher fish yield. The present study indicated that humic acid supported fish production, which offers considerable potential for aquaculture production enhancement. The total harvested weights of tilapia were $7416.2 ; 5896.1 ; 13081.4$; and $11644.8 \mathrm{~kg} / \mathrm{pond}$ for the same sequence treatments Table (5). These results indicated that the humic acid improved water quality, hence led to significantly increase in fish production.

Highest production of different fish species were achieved in the humic acid treatments and had significantly higher $(\mathrm{P}<0.05)$ values than in the same treatments without substrate without humic acid. Tilapia is regarded as an omnivorous species and capable of feeding on benthic and attached algal and detrital aggregates (Azim et al., 2003a and b).

It is hypothesized that the increases in net yields of fish were largely a result of the availability of easily grazed periphytic food growing on the humic acid. Similar degrees of enhancement of production of $L$. rohita were obtained by (NFEP, 1997 and Wahab et al., 1999) through the addition of substrates.

\section{Conclusion}

The present study concluded that effects of humic acid on water parameters have a large advantages since, the physico-chernical parameters studied were improved and the plankton composition documented gave average requirement for all the parameters needed for fish growth and survival, the fluctuation accounted for the different fish yields, while the ponds waters were suitable for fish production.

\section{References}

Adolf, J. E; Bachvaroff, T. R and Place, A. R. (2009). Environmental modulation of karlotoxin levels in strains of the cosmopolitan dinoflagellate Karlodinium veneficum (Dinophyceae). J Phycol, 45: 176-192.

APHA. (2000). Standard Methods for the Examination of Water and Wastewater. $21^{\text {st }}$ edition. Eaton, A.D., Clesceri, L.C. and Greenberg, A.E. (eds.). American Public Health Association, Washington, DC.

APHA. (1985). American Public Health Association Standard Methods for the examination of water and waste water $15^{\text {th }}$ edition. Pp 476. 
Avci, M.; Denek, N. and Kaplan, O. (2007). Effects of Humic acid at different levels on growth performance, Carcass Yields and some biochemical parameters of quails. Journal of Animal and Veterinary Advances, 6 (1): 1-4.

Azim M.E.; M.A. Wahab; P.K. Biswas; T. Asaeda; T. Fujino; and M.C. Verdegem. 2005. The effect of periphyton substrate density on production in freshwater polyculture ponds. Aquac., 232: 441-453.

Azim M. E.; Verdegem, M. C.; Singh, M.; Dam, A. A. and Beveridge, M. C. (2003b). The effects of periphyton substrate and fish stocking density on water quality, phytoplankton, periphyton and fish growth. Aquac. Res., 34: 685-695.

Azim, M. E.; Verdegem, M. C.; Mantingh, I.; Van Dam, A. A. and Beveridge, M. C. M. (2003a). Ingestion and utilization of periphyton grown on artificial substrates by Nile tilapia, Oreochromis niloticus. L. Aquac. Res., 34: 85-92.

Bakhsh, H. K., (2001) Influence of Humic Acid on Water Quality and Growth of Algae in Freshwater Ecosystem. Masters thesis, Universiti Putra Malaysia.

Brett, M. T. and Goldman, C. R. (1996). Ameta-analysis of the freshwater trophic cascade. Proc. Acad*Sci.USA, 93: 7723-7726

Carlsson, P.; Graneli, E.; Tester, P. and Boni, L. (1995). Influences of riverine humic substances on bacteria, protozoa, phytoplankton and copepods in a coastal plankton community. Mar. Ecol.Prog. Ser. 127: 213-221

Conzonno, V. H. and Cirelli, F. A (1996). Humic substances and phytoplankton primary production in chascomus pond (Argantina). Facts and Speculations. Rev. Asoc.Cienc.Nat.Litoral 27(1): 35-42.

Crisman, T. L. and Beaver, J. R. (1990). Application of planktonic biomanipulation for managing eutrophication in the subtropic. Hydrobiologia, 200/201: 177-185.

Diana, J. S.; Dettweiler, D. J. and Lin,C.K.(1991). Effect of Nile tilapia (Oreochromis niloticus) on the ecosystem of aquaculture ponds, and its significance to the trophic cascade hyphothesis. Can.J.Fish.Aquat.ScL,48:183-190.

Elhigzi, F. A. R.; Haider, S. A. and Larsson, P. (1995).Interactions between Nile tilapia (Oreochromis niloticus) and cladocerans in ponds (Khartoum, Sudan).Hydrobiologia, 307:263-272.

Gutseit, K.; Berglund, O. and Graneli, W. (2007). Food quality for Daphnia in humic and clear water lakes. Freshwater Biology, 52:344-356.

Hansson, L. A.; Nicolle, N.; Brodersen, J.; Romare, P.; Nilsson, P. A. and Brönmark, C. (2007). Consequences of fish predation, migration, and juvenile ontogeny on zooplankton spring dynamics. Limnology and Oceanography, 52: 696-706. 
Hessen, D. O.; Andersen, T.; Lyche, A. (1989). Differential grazing and resource utilization of zooplankton in a humic lake. Arch Hydrobiol. 114: 321-347.

Huchette, S. M.; Beveridge, M. C.; Baird, D. J. and Ireland, M. (2000). The impacts of grazing by tilapias (Oreochromis niloticus) on periphyton communities growing on artificial substrate in cages. Aquac., 186: 45-60.

Janik, J. J. (1989). Nutrient recycling in Castle Lake, California: Phytoptanktonzooplankton interactions. Diss. ABST.-TNT.-PT.-B.-and- ENG. 49(8):141.

Kankaala, P. (1988). The relative importance of algae and bacteria as food for Daphnia longispina (Cladocera) in a polyhumic lake. Freshwat. Biol., 19: 285-296.

Keskitalo, J. and Eloranta, P. (eds.) (1998) Limnology of Humic Waters. Leiden: Backhuys.

Klochenko, P.D.; Vasilchuk, T. A.; Medved, V. A. and Vasilenko, O. V. (2011). Peculiarities of the Influence of Humic Acids on the Development of Plankton Algae. Hydrobiological Journal, 47 (1).

Meinelt, T. ; Pietrock, M.; Wienke, A. and Volker, F. (2003). Humic substances and the water calcium content change the toxicity of malachite green. Journal of Applied Ichthyology, 19, 380-382

NFEP. (1997). Production enhancement of the Indian major carp, Labeo rohita (Ham.) using bamboo trimmings as a substrate for the growth of periphyton. NFEP Paper No. 10. Northwest Fisheries Extension Project, Parbatipur, Dinajpur, Bangladesh.

Nehad, K. and Howayda, H. A. (2010). Some Investigations on Zooplankton and Biochemical Contents content of phytoplankton in Wadi El-Rayan Lakes, Egypt. World Applied Science Journal, 11(9): 1035- 1046.

Prakash, A.; Rashid, M. A. and Jensen, A. (1973). Influence of humic substances on the growth of marine phytoplankton: diatoms. Limnol. Oceanogr. 18:516-524.

Prescott, G. W., (1962). Algae of the Western Great Lakes Area, P: 517. Brown, W. M. C. Com. USA.

Ramesh, M. R.; Shankar, K. M.; Mohan, C. V. and Varghese, T. J. (1999). Comparison of three plant substrates for enhancing carp growth through bacterial biofilm. Aquac. Eng., 19: 119- 131.

Richardson, W. B.; Wickham, S. A. and Threlkeld, S. T. (1990). Food web response to the experimental manipulation of a bentivore (Cypinus carpio), zooplankton (Menidia heryllina) and benthic insects.Arch.Hydrobiol,119:143-165.

Sarir, M. S.; Durrani, M. I. and Mian, A. I. (2006). Effect of the source and rate of humic acid on phosphorus transformations. Journal of Agricultural and Biological Science, 1: 29-31 
Sánchez-Marín, P. and Beiras, R (2011). Adsorption of different types of dissolved organic matter to marine phytoplankton and implications for phytoplankton growth and $\mathrm{Pb}$ bioavailability. Journal of Plankton Research, 33: 9Pp. 1396-1409

Shaker, I. M. (2008). Effect of using different types of organic manure (compost; chicken, mycelium) and mineral fertilizer on water quality, plankton abundance and on growth performance of Oreochromis niloticus in earthen ponds. Abbassa. Int. J. Aqua. (1A): 203-227.

Shaker, I. M. and Mahmoud, A. A. (2007). The biological load of silver carp cages in Nile River and effects of their on water quality \& growth performance. Egypt. J. Aquat. Biol. \& Fish., 11 (2): 119-143.

Shaker, I. M. and Abdel-Aal, M. (2006). Growth performance of fish reared under different densities in semi-intensive and extensive earthen ponds. Egypt. J. Aquat. Biol. \& Fish., 10 (4): 109-127.

Shaker, I. M.; Mona, A. H. and Mahmoud, A. A. (2009). Effect of periphyton substrate on water quality and growth performance of Nile tilapia in earthen ponds. Abbassa Int.J. Aqua., Special Issue for Global Fisheries \& Aquaculture Research Conference, Cairo International Convention Center, 24-26 October, pp 741-763.

Shaker, I. M; Abou Zeid, M. Y. and Batran, A. (2013): Effect of using periphyton substrate (bamboo stems) on water quality, phytoplankton, zooplankton, periphyton and growth performance for tilapia, mullet and catfish in earthen ponds. Abbassa, Int., J. Aqua., 6 (No 1): 108-139.

Shannon, C. R. and Weaver, W. (1949). The Mathematical Theory of Communication. Urbana University Press, Urbana, Illinois, $117 \mathrm{pp}$.

Singh, C. P. and Amberger, A. (1991). Solubilization and availability of $\mathrm{P}$ during decomposition of rock phosphate enriched straw and urine. Biol. Agric. Hort, 7: 261.

Smith, D. W. and Pledrahita, R. H. (1988). The relation between phytoplankton and dissolved oxygen in fish ponds. Aquaculture, 68: 249-265.

Statistical Analysis System (SAS). (2000). SAS program Ver 6.12, SAS institute incorporation, Cary, NC 27513 USA.

Steinberg, T. M; Timofeyev, M. A; Bittner, .M. and Menzel, R. (2008) Review Series Humic Substances Part 2: Interactions with Organisms. Env Sci Pollut Res, 15 (2): 128 - 135.

Sun, B. K; Tanji, T. and Unno, H. (2006). Extinction of cells of cyanobacterium Anabaena circinalis in the presence of humic acid under light. Appl Microbiol Biotechnol., 72: 823-828.

Taniguchi, G. M.; Bicudo, D. C. and Senna, P. A. C. (2005). Gradiente litorâneolimnético do fitoplâncton e ficoperifíton em uma lagoa da planície de inundação do Rio MogiGuaçu. Revista Brasileira de Botânica., 28: 137147. 
Thompson, F. B.; Abreu, P. C. and Wasielesky, W. (2002). Importance of biofilm for water quality and nourishment in intensive shrimp culture. Aquac., 203: 263- 278.

Vrana, D. and Votruba, J. (1995). Influence of soluble humic substances on the of Algae and Blue-Green Algae. Folia Microbiol., 40 (2) : 207-208.

Wahab, M. A.; Mannan, M. A.; Huda, M. A.; Azim, M. E.; Beveridge, M.C. and Tollervey, A.G. (1999). Effects of periphyton grown on bamboo substrates on growth and production of Indian Major carp rohu (Labeo rohita Ham.). Bangladesh J. of Fisheries Res., 3: 1-10.

Wet, L .F. and Visagie, W. (2010). Evaluating CHD-FA Carbohydrate-Derived Fulvic Acid for Use in Diets of Mozambique Tilapia Oreochromis Mossambicus. Feed Technology Group Division Aquaculture University of Stellenbosh South Africa.

Zaret,T. M. (1980). Predation and freshwater communities. New Haven and London, Yale Univ. Press, 187pp. 


\title{
تاثير استخدام حامض الهيوميك على الهائمات وجودة المياة ونمو أسماكك البلطى البطى النيلى فى أحواض الإستزراع السمكى وجلئ
}

\author{
محمد جمعه بطاح"، عايدة محمد عبدالله ضوة 2 ، أيمن أنور عمار² ، محمد مختار سلامة 2 \\ 1- قسم النبات شعبة المبكروبيولوجى كلية العلوم جامعة بنها. \\ 2- المعل المركزى لبحوث الثروة السمكية بالعباسة.
}

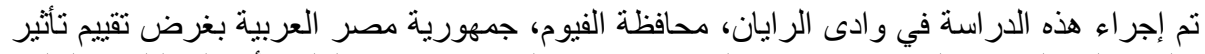

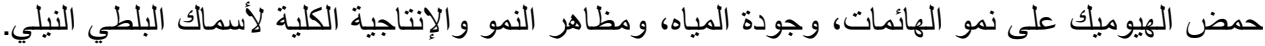

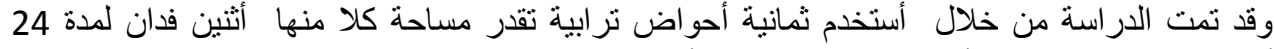

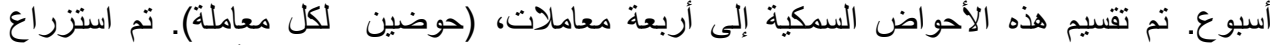

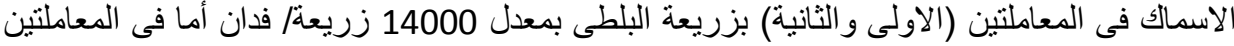

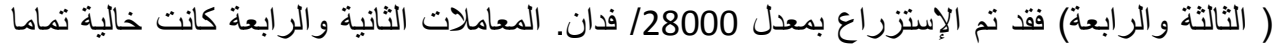

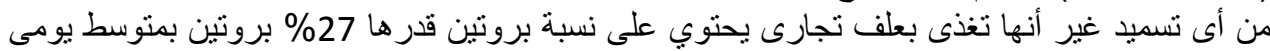

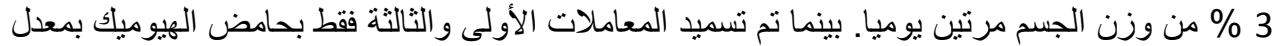
3 كجم / فدان أثناء إعداد الأحواض باض بالاضافة الى 1.5 كجم من سماد الهيوميك لكل طن عليقة أثناء

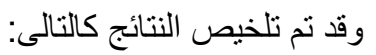

1- لا توجد فروق ذات دلالة إحصائية في درجة حرارة الماء أو القلوية الكلية أو عسر الماء أو درجة

الملوحة.

2- - تركيزات الأمونيا ، و الأوكسجين الذاب، الفوسفات الذائب، الكلوروفيل أعلى فى كل من المعاملتين الأولى و الثالثة عنه فى المعاملتنين الثانية و الرابعة.

3- نركيزات النترات والنتريت أعلى بأحواض المعاملتين الرابعة والثانية عنه فى المعاملتين الأولى و الثالثة.

4- سجلت أقل قيمة للثافية فى كلا من المعاملة الاولى والثالثة بينما رصدت أعلى قيمة لها بالمعاملة

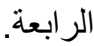

5- أعلى تركيز من الهائمات ( النباتية والحيو انية ) كان بالمعاملة الأولى ثم الثانية يليه المعاملة الثالثة.

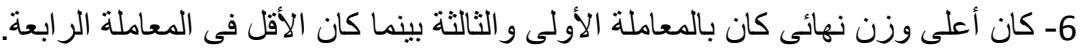

